\title{
A környezeti hatások értékelésének lehetősége ökoszisztéma-szolgáltatások alapján
}

\author{
Environmental impact valuation using \\ ecosystem services
}

\author{
DOMBI MIHÁLY
}

KULCSSZAVAK: környezetpolitika, környezeti hatások, környezeti vizsgálat, ökoszisztémaszolgáltatások, megújuló energiaforrások

\begin{abstract}
ABSZTRAKT: A környezetpolitika egyik elsődleges célja az emberi tevékenység negatív környezeti hatásainak minimalizálása. Tanulmányom célja a makroszintú tervezéshez való hozzájárulás a környezeti hatások elemzésének az ökoszisztéma-szolgáltatások elméletére alapozott módszertani keretével. Röviden elemzem a környezetpolitikai döntéseket megnehezítő tényezőket, majd felvázolom az elemzés módszerét, amelynek gyakorlati alkalmazását is bemutatom a megújuló energiaforrásokra alapozott technológiák káros környezeti hatásainak alapján történő összehasonlítás révén. A tanulmány legfontosabb eredménye maga a környezeti vizsgálatot támogató módszer, amely korlátait figyelembe véve - alkalmazható fejlesztési tervek és programok megelőző (ex ante) értékelésére, valamint különböző regionális vagy országos szintü, környezeti hatással rendelkező vagy környezetvédelmi célú szabályozások (törvények, rendeletek, határozatok) előzetes hatásvizsgálatára. Az esettanulmány során kapott eredmények is fontos információval szolgálnak az ökoszisztáma-szolgáltatások értékével és a megújuló energiaforrások környezeti hatásaival kapcsolatban. Magyarországon az ökoszisztéma-

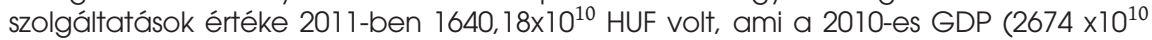
HUF) 61,3\%-a. A megújuló energiaforrásokhoz köthető negativ környezeti hatások tekintetében a legelönyösebbek a szél- és a napenergia (10,2, ill. 11,8\%), közepesen környezetterhelő a geotermikus energia hasznosítása (22,6\%), a legjelentősebb mértékú káros környezeti hatás pedig a biomassza és a vízenergia-hasznositás esetén (63,5, ill. 54,7\%) figyelhető meg.
\end{abstract}

KEYWORDS: environmental policy, environmental impacts, environmental appraisal, ecosystem services, renewable energy sources

ABSTRACT: The harmful impacts of civilisation are observable in every activity nowadays. One of the main goals of environmental policy is to minimise harmful environmental impacts of human activity. The contribution of this study to macro-scale planning consists of a methodical frame for environmental appraisal based on the theory of ecosystem services, i. e. the multitude of benefits derived from resources and processes supplied by natural ecosystems.

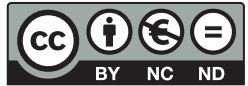


Difficulties connected with decision making in environmental politics are briefly analysed. The weaknesses of various environmental valuation methods are discussed, $i$. e. the number and structure of stakeholders, the hierarchy of impacts, the deliberation processes and the complexity of assessments. Former methods of environmental appraisal of macro-scale development policies and planning are presented and the theory of ecosystem services as well as their valuation methods are described.

In the next part, a method is proposed and its potential application is demonstrated by a case study of renewable-energy-based technologies regarding their relative environmental impacts. The impacts of RES technologies were collected from pertinent literature.

The most important result of the study is a potentially new method for environmental assessment (repetition). It might be a useful tool for ex ante valuation of development plans and programmes as well as for prior environmental audits for various regional or national regulation purposes aiming at environmental protection or determining environmental impacts. Naturally, limits of the method have to be taken into account

The results of the case study provide useful information about the value of the ecosystem services and the harmful environmental impacts of some renewable energy sources. In 2011, the value of ecosystem services in Hungary was $1640.18 \times 10^{10}$ HUF, which is 61.3 percent of Hungarian GDP $\left(2674 \times 10^{10}\right.$ HUF in 2011). The utilisation of the energy of wind and sun is the most beneficial (10.2\% and $11.8 \%$, respectively) regarding environmental impacts connected with renewable energy sources. The utilisation of geothermal energy is characterised by a medium-level of environmental pressure (22.6\%), while the most negative impacts are observed in the case of bioenergy and water energy utilisation (63.5\% and 54.7\%).

\section{Bevezetés}

A földi bioszféra állapota egyre égetőbb, összetett globális krízissel jellemezhető, amelyet egyértelmüen az emberi tevékenység okozott. Az emberiségnek meg kell változtatnia életmódját, át kell értékelnie a szükségleteit, azok kielégítésének módját. Az előttünk álló feladat megoldása komplex megközelítést igényel, ezért a környezeti problémák megoldását célzó tevékenység - a környezetpolitika - szükségszerűen átfogó, interdiszciplináris terület.

A környezetpolitika nem ágazati, hanem horizontális politika: mivel a környezetpolitikai célok átfogóak, ezért minden, az adott társadalom és térség jövőjét érintő folyamatot környezeti szempontok szerint is értékelni kell. A környezetpolitika célja a megelőzés, a környezeti állapot javítása, végső esetben pedig a várható negatív hatások minimalizálása. A környezeti hatások valós értékelésének lehetőségét azonban véleményem szerint egyes tényezők kifejezetten torzíthatják, ezekre később részletesen kitérek:

1. A társadalom bevonása a környezeti hatások értékelésébe helytelen következtetésekre vezethet az adott csoport érintettsége miatt. A helyi közösségek érdekeinek, véleményének figyelembevételével párhuzamosan törekedni kell az objektívebb értékelési módszerek alkalmazására is. 
2. A számtalan lehetséges környezeti hatás nem egyenrangú. Az ökológiai problémák esetében a globális-lokális összetettség mentén valamilyen hierarchiaszerü felépítést, prioritást, súlyozást kellene érvényesíteni.

3. A problémák összetettsége, a potenciális hatások száma és mértéke a helyi szinttől a makroszint felé növekszik.

Tanulmányom célja, hogy a makroszintű tervezéshez járuljon hozzá a hatások elemzésének egy új lehetőségével. Bemutatok egy lehetséges, az ökoszisztéma-szolgáltatások elméletére alapozott, környezetpolitikai döntések kompetenciájának növelését elősegítő módszertani keretet. Ezt követően ismertetem gyakorlati alkalmazását a megújuló energiaforrásokra alapozott technológiák káros környezeti hatásainak összehasonlítása esetén.

\section{A környezeti értékelés alapvető kérdései}

A környezetpolitika egyik alapvető eleme az egyes ágazatok, tervek és programok, valamint beavatkozások környezeti hatásának vizsgálata. Tanulmányomban azon környezetpolitikai vizsgálati eszközökre koncentrálok, amelyeknek célja a környezeti hatások releváns értékelése, a különböző beavatkozások környezeti szempontú vizsgálata.

„A környezeti értékelés fogalomkörébe minden olyan tevékenység beleértendo", amely a környezetben lejátszódó antropogén vagy természeti eredetü folyamat, jelenség vagy környezeti elemben és rendszerben bekövetkezö állapotváltozás megfigyelését, a változások irányának és mértékének rögzitését (mérését) [...] és fenntartó tervezési tevékenységek és beavatkozások hatékonyságát és hatásosságát vizsgálja" (Czira 2003, 11.). Ennek megfelelően célom éppen a változások, hatások irányának és mértékének minél pontosabb és megalapozottabb meghatározásához, azok összehasonlíthatóságához való hozzájárulás.

A környezeti értékelés célja sokrétü, a téma szempontjából kiemelkedő az információszolgáltatás, a tervezés támogatása és a döntés-előkészítés. E célra számos módszer és módszer-kombináció alkalmazható, Czira Tamás (2003) a teljesség igénye nélkül 15 ilyen módszert sorol fel, többek között: környezeti hatásvizsgálat, stratégiai környezeti vizsgálat, környezeti konfliktusértékelés, fenntarthatósági értékelés.

Bela Györgyi és munkatársai (2003) „,a környezetpolitikában alkalmazható döntéstámogató modellekröl és értékelési eljárásokról" (7. old.) adott áttekintésükben kevesebb lehetséges módszert említenek, bár ezek csak részben környezetértékelési módszerek, alkalmazásuk ennél szélesebb körủ lehet. A bemutatott módszerek:

- költség-haszon-elemzés (Cost-benefit Analysis - CBA);

- többszempontú döntéstámogatás (Multi-Criteria Decision Aid - MCDA);

- állampolgári tanácsok (Citizens' Jury - CJ);

- környezeti hatásvizsgálat (Environmental Impact Assessment - EIA); 
- alkalmazkodó környezetértékelés és környezetgazdálkodás (Adaptive Environmental Assessment and Management - AEAM);

- konstruktív technológiaértékelés (Constructive Technology Assessment - CTA);

- részvételen alapuló vidékértékelés (Participatory Rural Appraisal - PRA);

A felsorolt módszerek mindegyikét bizonyos torzítások terhelik, amelyek véleményem szerint a társadalmi részvétel fokozása és a tiszta szakértői módszerek alkalmazása közti ellentétre, a bevezetésben említett „hatáshierarchia”, illetve a makroszintű értékelés nehézségeire vezethetők vissza.

Málovics és Bajmócy (2009) a klasszikus környezet-gazdaságtan értékelési eljárásait állítja szembe az ökológiai gazdaságtan által szorgalmazott deliberatív eljárásokkal. A monetarizáción alapuló környezeti értékelésnek valóban megvannak a hátrányai:

1. a használattal nem összefüggő értékrészek meghatározására kevésbé alkalmasak;

2. lineáris kapcsolatokat feltételeznek;

3. áttételes kapcsolat áll fenn az értékelt jószág és az érintett természeti erőforrás között (valós piacok hiánya, illetve hipotetikus piacok képzésének nehézségei).

Az idetartózó metódusok előnye ugyanakkor, hogy könnyen hozzáférhető adatok alapján értékelnek nehezen tárgyiasítható, értékelhető erőforrásokat, így a döntéshozók számára könnyen értelmezhető iránymutatással szolgálnak (Marjainé 2005).

Az ökológiai közgazdaságtan elvei szerint a környezeti döntések során fokozottan ügyelni kell a társadalmi részvételre. Az ökológiai gazdaságtani megközelítés szerint az állampolgári magatartás gyakorlása során az egyének teljesen más preferenciákkal jellemezhetők, mint a fogyasztás során: jellemző rájuk az altruizmus. Az emberek tehát „multiracionálisak”, és az adott szituációban dől el, hogy döntéseikben melyik „énjüket” követik (Málovics, Bajmócy 2009). Az egyének preferenciái ezek szerint nem mindig ugyanúgy és ugyanolyan mértékben érvényesülnek, a helyzetet pedig tovább bonyolítja, hogy a preferenciák változékonyak és endogének (Málovics, Bajmócy 2009, Costanza 2003). Ez egyrészt azon monetáris értékelési eljárások gyengeségét mutatja, amelyek a preferenciákra alapozzák egyes javak értékelését (feltárt és kinyilvánított preferenciaeljárások), másrészt viszont megkérdőjelezik a társadalmi részvétel megalapozottságát, hiszen a preferenciák ezek szerint akár rosszindulatúan is változtathatók.

Szintén a társadalmi részvétel mellett érvel Málovics és Bajmócy (2009, 478.), amikor azt állítja, hogy „,ha még a természet pénzbeli értékelése pusztán a döntést befolyásoló tényező́k egyike, (...) akkor sem léteznek „objektív” szakértők, csak eltéro", versengő tudományos álláspontok". A társadalmi részvételben azonban szintúgy nem figyelhető meg az egységes fellépés: egy deliberatív folyamat számos résztvevojét is jellemzi bizonyos egyéni, illetve csoportérdek mentén érvényesülő megosztottság - persze azon csoportok között, amelyek nem maradtak ki az egyeztetésből gyengébb érdekérvényesítő képességük miatt (Szirmai et al. 2005). 
Bela Györgyi és munkatársai (2003) szerint a környezetpolitikai döntésekben való társadalmi részvétel előnye a lakosság helyismerete, a politikai kockázat csökkentése és a társadalmi, közösségi tanulási folyamat maga; míg hátránya az elfogultság, az idő- és költségigényesség, a szakmaiság hiánya és a rossz döntések veszélye.

A környezetvédelem kibontakozását a fejlett államokban a társadalomnak a gazdaságra és az államra gyakorolt nyomása biztosította, ugyanakkor a környezeti problémák megítélése nem a károk mértéke alapján, és nem objektíven, hanem „érdekkötött módon” történik. Ezen érdekeket különböző társadalmi szükségletek és igények mozgatják (Szirmai 1999). Éppen ezért szükségszerű a különböző érdekek okozta szubjektivitás szintjének csökkentése, még akkor is, ha elméletileg a természet érdekeinek védelmét egyes társadalmi csoportok vállalják, vállalhatják, hiszen ezek nem feltétlenül egyeznek meg a helyi lakossággal.

Kisebb-nagyobb környezeti hatása minden emberi tevékenységnek van, és ezek hatálya nem határolható le elég egyértelmüen térben és időben, az egyes döntések nem csak a helyi társadalomra vannak hatással. Joguk volna a deliberációs folyamatban részt venni a jövő nemzedékeknek, de azon jelenben élőknek is, akikre akár csak kismértékben is hat az adott beavatkozás. Az ÜHT-gázok kibocsátását érintő esetekben például ez a 7 milliárd embert - és utódaikat - jelentené.

Ez viszont még mindig nem teszi ki az érintettség és érdekeltség teljes körét. Az ember csupán egy kis része a számos kölcsönhatással jellemezhető, nagy komplexitású ökoszisztémának: a környezetpolitikai tervezésbe ugyanolyan jogon érdemelne beleszólást a teljes földi flóra és fauna (Lányi 2007), bár ez a felvetés túlidealizált, erősen elméleti. A helyi közösségek tehát túlreprezentáltak lehetnek a döntések és a tervezés során az ökoszisztéma más elemeihez képest.

Az érintettség kérdése tovább bonyolódik, amint lokális szinttől a regionális, majd a globális szint felé távolodunk. Kételkedem az egyének állampolgári, altruista preferencia-rendszerében olyan esetben, amikor a saját magukra visszaható és az általuk közvetlenül nem érzékelhető hatásokat kell összevetniük. A helyzet a költségek viselése esetén ugyanilyen, csak fordított előjellel. Ez a probléma a deliberatív és a monetarizáción alapuló környezeti értékelést is terheli a lokális szinttől távolodva - a környezetpolitikai tervezés színtere döntő részben azonban ennél általánosabb.

Természetesen nem szeretném következtetésként levonni a deliberatív eljárások alkalmatlanságát, hiszen a környezeti problémák és hatások ismerete, egzakt megismerése nélkülözhetetlen bármilyen értékelési eljárás során. A környezeti tervezés olyan eszközök és módszerek alkalmazását igényli, amelyek a lehető legobjektívabban leírják és értékelik a környezetben bekövetkező változásokat. A tanulmányomban bemutatott módszer segítségével ezen objektivitás fejleszthető. 


\section{A makroszintú környezeti értékelés egyes esetei a magyar fejlesztéspolitikában}

A fejlesztéspolitikai tervek környezeti hatásainak értékelésére szolgáló módszerek lehetnek egyszerű értékelési eljárások, hatásorientált értékelési módszerek és értékrendalapú értékelési módszerek. Ezek közül csak az utóbbi alkalmas a szinergikus hatások és a területi hatások kimutatására. Ennek eszközei a mátrixmódszer, a pontozási módszerek és az alternatívák kidolgozása (Czira 2003).

Magyarországon az országos és regionális szintű fejlesztési tervek környezeti értékelései többnyire a stratégiai környezeti vizsgálati (SKV) módszer segítségével készültek. Az SKV-módszer a fenntarthatósági értékelésre is alkalmas, ebben az esetben a programokat egy fenntarthatósági értékrenddel vetik össze (Pálvölgyi, Csete 2011); az alábbiakban bemutatott SKV-k többsége tartalmaz ilyen vizsgálatokat. „A stratégiai környezeti vizsgálat alkalmas arra, hogy a fejlesztéspolitikában, a területi tervezésben és a területfejlesztésben érvényesítse a környezetvédelem, a környezeti politika érdekeit" (László, Varjú 2010). Az SKV a tervvel párhuzamosan készül, így elméletileg „menet közben jutnak érvényre a környezeti érdekek" (Varjú 2009).

A Nemzeti fejlesztési terv Regionális operatív programjához (ROP) készült stratégiai környezeti vizsgálat (Tombácz et al. 2003) magas színvonalú szakértői elemzés, amely precízen azonosítja az összes környezeti hatást. Az OP intézkedéseit fenntarthatósági értékrenddel veti össze, és ennek alapján tesz javaslatokat. Az Új Magyarország vidékfejlesztési stratégiai terv és program (ÚMVP) környezeti vizsgálata (Czira et al. 2006) jelentős társadalmi részvétellel zajlott. Az értékelés a várható környezeti hatásokat szintén fenntarthatósági értékrend tekintetében vizsgálja, de itt már a vizsgálatot végzok "fenntarthatósági értékelo" mátrixban" pontozással (-2/+2 skálán) értékelték a hatásokat. A vizsgálat készítői jelzik, hogy ez csupán „, analitikus javaslattevő eszköz”.

A „Tanulmányok a Duna hajózhatóságának javításáról” program inkább lokális skálán értékelhető program (VITUKI 2009). Az igen hosszú szakmai elemzés környezeti értékelésének módszere is súlyozás nélküli pontozás értékelő mátrix alapján, szintén -2/+2 skálán.

Az ÚMFT stratégiai környezeti vizsgálatai (Szilvácsku 2007a, 2007b) már egységes módszertan alapján készültek. A módszer a Stratégiai értékelő módszertani alapvetés névre hallgat (SÉMA), és korszerű DPSIR ${ }^{1}$-modellre épül. A környezeti hatások mértékének feltárása szempontjából azonban visszalépést jelent, hogy itt már a pontozás sem jelenik meg, hanem csak szöveges értékelés, bizonyos fenntarthatósági szempontok alapján. A 2030-ig szóló Nemzeti energiastratégia környezeti vizsgálata az ÚMVP-vel megegyező, tehát pontozásos módszerrel készült. 


\section{Ökoszisztéma-szolgáltatások}

Az egyes környezeti szempontú értékelések során az eddigiekben mindig felmerült valamilyen tényező, amely hátráltatta a hatásvizsgálatot. Az eddigi módszerek kevéssé alkalmasak a környezeti hatások objektív összevetésére, ezért tartottam fontosnak, hogy olyan irányban keressek megoldást, ahol az értékelés egzakt, független, kvantitatív alapja biztosított.

A következő fejezetekben az ökoszisztéma-szolgáltatások elméletét mutatom be, majd leírom, hogyan alkalmazható azok értékelése a környezeti vizsgálat céljaira. Robert Costanza és munkatársai (1997) tanulmányára alapozva alakítottam ki egy lehetséges értékelési keretet, amelyet minden korlátját figyelembe véve is hasznos, újszerű megközelítésnek tartok.

Az ökoszisztéma-szolgáltatások fogalma a 20. század végén jelent meg erőteljesen a természet- és társadalomtudományok határterületein. Az ökoszisztémaszolgáltatás „az emberiség hasznát jelenti az ökoszisztémákból, azaz azon javakat és szolgáltatásokat, amelyeket az ember élete során közvetlenül vagy közvetve felhasznál". A természettől „kapott”, gyakran esszenciális javakat és szolgáltatásokat értjük ökoszisztéma-szolgáltatásokon (Báldi 2011). A későbbiekben az ökoszisztémaszolgáltatásokat és -javakat együtt, szolgáltatásokként tárgyalom.

Az ökoszisztéma-szolgáltatások és -javak alapvetően a négy ökoszisztémafunkcióra vezethetők vissza: szabályozás, élőhely, produkció és információ (de Groot et al. 2002), ezek a különböző ökoszisztéma-szolgáltatások forrásai. Alapvetően három csoportot különböztethetünk meg: ellátó/termelő (pl. élelmiszer, nyersanyag, genetikai bázis), szabályozó (pl. klíma-, egyedszám-, eróziószabályozás; beporzás) és kulturális (pl. rekreáció, táj) szolgáltatásokat (Kelemen 2009).

Az ökoszisztéma-szolgáltatások vizsgálatával egyrészt becsülhetjük a különböző beavatkozások hatását az ökoszisztémára, másrészt viszont az ökoszisztéma-szolgáltatások fogalomköre a társadalomtudományok eszköztárát is bővítheti (Kovács et al. 2011). Ezen szolgáltatások pénzben értékelhetők, ami lehetővé teszi egyes folyamatok hatásainak gazdasági értékelését, így értékük vagy értékcsökkenésük - döntéshozatali rendszerbe illeszthető, és segíti a környezetpolitikai tervezést (Báldi 2011, Czúcz et al. 2011). Tanulmányomban ezzel a lehetőséggel élek, hiszen célom a környezeti hatások értékelése az ökoszisztéma-szolgáltatások segítségével.

\section{Az ökoszisztéma-szolgáltatások értékelése}

Az egyes ökoszisztéma-szolgáltatások értékelésére számos, a környezetgazdaságtan által megalkotott és elismert módszer, valamint deliberatív (kvalitatív) értékelési eljárás is alkalmazható (de Groot et al. 2002). A környezetgazdaságban alkalmazott kvantitatív módszerek alapján a szolgáltatások pénzben értékelhetők. A monetarizáció történhet a fejlesztési költségek alapján, illetve az 
egyéni preferenciák segítségével, keresleti görbe segítségével. Marjainé (2011) szerint ez utóbbiak az elméletileg helyes eljárások.

Hein és munkatársai (2006) szerint az ökoszisztéma-szolgáltatások értéke a szolgáltatások és az érintettek dinamikus kapcsolatától függ. A szerzők az összehasonlíthatóságot tartják elsődlegesnek, így az általuk javasolt módszertani keretben megengedett a pénzbeli és a nem monetáris értékelés egyidejü használata. A szerzők által bemutatott esettanulmány ennek ellenére csak monetáris értékeléseket tartalmaz az egyes szolgáltatásokra vonatkozóan, amelyek különféle környezetértékelési módszerek kreatív alkalmazásai.

Az ökoszisztéma-szolgáltatások értéke megközelíthető az egyik alapvető szolgáltatás kiemelésével is. Xie és munkatársai (in: Zang et al. 2011) az agrárium élelmiszer-termelése mint ellátótípusú ökoszisztéma-szolgáltatás alapján vezették le az összes többi szolgáltatás értékét.

A deliberatív eljárások az ökoszisztéma-szolgáltatások közösségi jóléthez való hozzájárulását értékelik; nagy előnyük, hogy ez esetben a szolgáltatások értékelése és a környezeti döntések előkészítése egy időben történhet. A hazai szakirodalomban a módszert Kelemen és munkatársai (2009) az Alpári-öblözet példáján mutatták be. A tanulmány kvalitatív, mélyinterjús módszertana azonban nem teszi lehetővé a változások kvantitatív összevetését.

Az ökoszisztéma-szolgáltatások jelentős része nem értékelhető gazdasági értelemben közvetlenül, piaci áruk alapján. Ezek a szolgáltatások tehát a gazdasági teljesítmény mérésének hatályán kívül esnek, így a bruttó hazai terméknek sem képezik részét. Az ökoszisztéma-szolgáltatások figyelembevételével kialakítható a reálisabb, környezeti értékeket is tartalmazó „zöld GDP” (Alexander et al. 1998). A szerzők azonban eltekintettek a szolgáltatások értékének jelentős összetevőitől: a használattal nem összefüggő értékrészek és a nem értékesített termékek eloállítását szolgáló ökoszisztéma-szolgáltatásoktól. A szerzők célja a teljes földi ökoszisztéma értékének meghatározása volt, ezért nem különböztettek meg eltérő típusú szolgáltatásokat - tanulmányom célját tekintve tehát ez a módszer nem alkalmazható. A globális ökoszisztéma értéke a szerzők különböző modellekre alapozott számításai alapján 8 és 16,2 billió dollár $\left(10^{12}\right.$, 1987-es USD) közötti, ami az 1987. évi globális GDP 44-88\%-a.

Az általam alkalmazott hatásértékelési módszer alapjául szolgáló ökoszisztéma-szolgáltatások értékeléssel szemben támasztott kritériuma a szolgáltatások teljes vagy legalább relatív, egymáshoz viszonyitott értékének meghatározására való alkalmasság volt. Céljaimnak az egyes ökoszisztéma-szolgáltatások pontos értékelése miatt a következő tanulmány által bemutatott eredmények jelentették a kiindulópontot.

Costanza és munkatársai (1997) a Nature-ben publikálták tanulmányukat az ökoszisztéma-szolgáltatások globális értékéről, amelyet évi 33 billió USD átlagértékre becsültek. Ez a globális GNI majdnem kétszerese (18 billió USD). A szerzők 17 szolgáltatást definiáltak, és ezek értékét 16 biom tekintetében különkülön meghatározták USD/ha/év dimenzióban (ökoszisztéma-szolgáltatási ko- 
1. táblázat: Az ökoszisztéma-szolgáltatások értéke az egyes biomokban, 1994-es USD-értékben Global value of the ecosystem services in certain biomes

\begin{tabular}{lc}
\hline \multicolumn{1}{c}{ Biom } & Érték, $10^{9}$ USD \\
\hline Nyîlt óceán & 8381 \\
Tengerpart & 12568 \\
Trópusi erdők & 3813 \\
Mérsékelt övi erdők & 894 \\
Gyepek, legelők & 906 \\
Mocsarak, lápok & 4879 \\
Folyók, tavak & 1700 \\
Sivatag & \\
Tundra & \\
Jég/szikla & \\
Szántó (mezógazdaság) & 128 \\
Beépített & \\
\hline Összesen & 33268 \\
\hline
\end{tabular}

A sötétitett cella az ökoszisztéma-szolgáltatások értékének elhanyagolhatóságát jelzi, az üres cellák pedig az adatok hiányát mutatják.

Forrás: Costanza et al., 1997, 256. p. alapján.

efficiensek). A cikk több mint 100 tanulmány eredményeinek szintézise. Az 1. táblázatban az ökoszisztéma-szolgáltatások értékének globális értékét láthatjuk az egyes fó biomokban. Az eredeti tanulmányban ezek további csoportosítása is megfigyelhető. Az adatokat 17 ökoszisztéma-szolgáltatás szerint értékelve a biomok összességében a szerzők megállapították, hogy a legjelentősebb szolgáltatás a tápanyagforgalom (51\%) értéke, amelyben kimagasló szerepe van a partvidékeknek, különösen az algáknak. Magas továbbá a kulturális szolgáltatások (9\%), illetve a hulladékasszimiláció (6,8\%) aránya, a többi szolgáltatás 1-5\% közötti értékekkel jellemezhető (Constanza et al. 1997).

A szerzők részletesen elemezték a számítás gyengeségeit és a módszer korlátait, amelyek közül a legfontosabbak a következők:

- egyes ökoszisztéma-szolgáltatások értékelése hiányos;

- az ökoszisztéma-szolgáltatások értékét feltáró tanulmányok többsége WTP²-számításra alapozott, ami időben változhat;

- lineáris keresleti függvényeket feltételeznek;

- az extrapoláció hibája: kis területek ökoszisztéma-szolgáltatási értékének globális vonatkoztatása;

- stock-értékek flow-értékre váltása 5\%-os diszkontráta használatával;

- ,pillanatfelvétel”-szerü statikus modellt alkalmaznak a dinamikus ökoszisztéma-szolgáltatásokra.

David Pearce 1998-ban publikált cikkében komoly bírálatokat fogalmaz meg az 1997-es tanulmánnyal szemben: „Costanza és szerzőtársainak cikke mélységesen elhibázott” (28. old.). A leginkább kifogásolt pontok: a WTP alkalmazása, a marginális WTP teljes Földre való vonatkoztatása, a globális ökoszisztéma-szol- 
gáltatások értékének GNI-t meghaladó mértéke. Ezeket a kifogásokat Costanza és szerzőtársai részletesen elemezték, álláspontjuk megvédésére az Environment szerkesztősége ugyanabban a számban lehetőséget adott. Costanza és munkatársai (1998) tovább tárgyalták a pénzbeli értékelés létjogosultságát, reagálva ezzel a tudományos közvélemény észrevételeire.

A Costanza és munkatársai által készített számítások természetesen a szolgáltatások értékelésének csupán nyers becslései. A tudomány máig adós maradt a további, komoly pontosítással, azonban a számítások feldolgozása, kisebb területekre való közvetlen alkalmazása mégis elterjedt (Chen, Zhang 2000, Lei 2003, Wang et al. 2005, 2011, Zhao et al. 2005, Zang et al. 2011). Két esetben kisebb módosításokkal alkalmazták a számításokat (Yu et al. 2004, Seidl, Moraes 2000).

\section{Az ökoszisztéma-szolgáltatások értékének lehetséges szerepe a környezeti vizsgálatban a megújuló energiaforrások példáján}

A különböző fejlesztéspolitikai tervek vagy egyes környezetpolitikai döntések során a környezeti vizsgálat szempontjából jelentős hiányosságok észlelhetők a környezeti hatások összehasonlíthatósága terén. Korábban már láthattuk, hogy a környezeti vizsgálatok során idáig nem sikerült „súlyozni” a káros környezeti hatásokat. A probléma természetesen felettébb összetett, mégis úgy gondolom, az ökoszisztéma-szolgáltatások értékelése hasznos megközelítés lehet, még ha pontossága nem is tökéletes.

A Costanza és munkatársai által 1997-ben közzétett számítások alapjait használom, mert máig nem született átfogóbb becslés az ökoszisztéma-szolgáltatások értékét illetően, és az ökoszisztéma-szolgáltatási koefficiensek által érvényesíthető a hatáshierarchia, a hatások eltérő léptéke és jelentősége. A szolgáltatások közvetlen felhasználásához a környezeti vizsgálatokban a hatásértékelés céljára el kell fogadnunk azt a logikai lépést, hogy az egyes káros környezeti hatások egy vagy több ökoszisztéma-szolgáltatásban minőségi kárt okoznak. Mivel tanulmányom célja a makroszintű értékelés megalapozása, eltekintek a hatás effektív, lokális helyszínétól. A hatások összevetésének módszere a következő lépésekből épül fel:

1. a káros hatások azonosítása,

2. az érintett/tervezési terület lehatárolása,

3. a vizsgált területen az ökoszisztéma-szolgáltatások értékének kalkulációja,

4. hatások összehasonlítása.

Az ökoszisztéma-szolgáltatások értékét tehát a teljes vizsgált területre kell kiszámítani, majd az egyes szolgáltatások arányát a teljes ökoszisztéma értékében az adott szolgáltatás súlyaként alkalmazzuk a hatások összevetésénél. A fejezet további részében a megújuló energiaforrások példáján keresztül mutatom be a számítások menetét. 
2. táblázat: A különböző megújuló energiaforrások környezeti hatásai Environmental impacts of several renewable energy sources

\begin{tabular}{|c|c|c|c|c|}
\hline Biomassza & $\begin{array}{c}\text { Geotermikus } \\
\text { energia }\end{array}$ & Szélenergia & Napenergia & Vízenergia \\
\hline $\begin{array}{l}\text { a biodiverzitás } \\
\text { csökkenése } \\
(11,12) \\
\text { talajdegradáció } \\
(3,6,7) \\
\text { légszennyezés } \\
(1,2,16) \\
\text { a vizek szennye- } \\
\text { ződése } \\
(4,5)\end{array}$ & $\begin{array}{l}\text { légszennyezés } \\
(1,2,16) \\
\text { hőszennyezés } \\
(2,12) \\
\text { zajhatás } \\
(12,16,17) \\
\text { vízszint- } \\
\text { csökkenés } \\
\text { (5) }\end{array}$ & $\begin{array}{l}\text { árnyékhatás } \\
(12,16,17) \\
\text { elektromágneses } \\
\text { interferencia } \\
(12,16,17) \\
\text { madár- és dene- } \\
\text { vérpusztulás } \\
(11,12) \\
\text { tájképi hatás } \\
(16,17) \\
\text { zajhatás } \\
(12,16,17)\end{array}$ & $\begin{array}{l}\text { tájképi hatás } \\
(16,17) \\
\text { a biodiverzitás } \\
\text { csökkenése } \\
(11,12) \\
\text { a ritka fémek } \\
\text { kitermelése } \\
(6,7)\end{array}$ & $\begin{array}{l}\text { a biodiverzitás } \\
\text { csökkenése } \\
(11,12) \\
\text { a vízjárás válto- } \\
\text { zása } \\
(4,5) \\
\text { a vízminőség } \\
\text { változása } \\
(4,5) \\
\text { talajdegradáció } \\
(3,6,7)\end{array}$ \\
\hline
\end{tabular}

A zárójelben az ökoszisztéma-szolgáltatás sorszáma található, melyre az adott hatás negatív irányban hat, lásd 3. táblázat. Forrás: saját szerkesztés.

A megújuló energiaforrások arányának növelése az energiagazdálkodásban - a hatékonyság és a takarékosság egyidejű növelésével - elkerülhetetlen feladat a 21. században. A megújuló energiaforrások azonban a technológiák igen széles, diverzifikált körével jellemezhetők, mindegyik esetén felléphetnek káros környezeti hatások kisebb-nagyobb mértékben. A megfigyelhető potenciális negatív hatásokat a 2. táblázatban gyüjtöttem össze szakirodalom alapján (de Almeida et al. 2005, Bobok, Tóth 2010, Cherubini, Stromann 2011, Dinya 2010, Josimovics, Pucar 2010, Kristmannsdóttir, Ármannsson 2003, McBridge et al., 2011, Phillips 2010, Rybach 2003, Saidur et al. 2011, Sembery, Tóth 2004, Stekuerová et al. 2008, Szalai et al. 2010, Szarka 2010, Szeredi et al. 2010, Tsoutsos et al. 2005) $)^{3,4}$. A káros hatások között csak azokat szerepeltettem, amelyek mindegyik vonatkozó közleményben szerepelnek és normál üzem mellett előfordulnak. A legtöbb esetben a vízkészletekre gyakorolt negatív hatás figyelhető meg (biomassza, geotermikus energia, vízenergia). A biodiverzitás csökkenésével az extenzív, magas területigényű energiatermelési módoknál számoltam (biomassza, napenergia), míg a vízenergia esetén ezt a hatást „az alvízoldali hidrológiai viszonyok változása" miatt szerepeltettem (Szeredi et al. 2010, 960. old.).

A megújuló energiaforrások természetesen jelentős környezeti haszonnal is járnak, amennyiben fosszilis energiahordozókat váltanak ki az energiatermelésben és a közlekedésben, vagy a helyi környezetre fejtenek ki pozitív, fejlesztő hatást. Tanulmányom a negatív hatások értékelésére korlátozódik, a továbbiakban azonban kibővitheto” a hatások egyfajta „környezeti mérlegének” vizsgálata céljából.

Kutatásaim során kénytelen voltam elvetni a megújuló energiaforrások környezeti hatásainak értékelése céljából esetlegesen hasznosítható egyes eljárásokat. A deliberatív eljárások a kvantifikálhatóság hiánya miatt, a keresleti görbét 
becslő eljárások pedig vagy a piac hiánya és a hipotetikus piac képzésének nehézségei miatt, vagy az érintettség köréből adódó torzulások miatt nem kerülhettek szóba. Ez utóbbi nehézség főleg a lokális-regionális környezeti hatások esetén torzította volna az eredményeket, például a tájképi hatás túlértékelése áttételesebb problémák (biodiverzitás, talajdegradáció) rovására. A költségalapú eljárások esetén az adatok szinte teljes hiánya okozott volna problémát.

A hatások összehasonlítása érdekében olyan általános értékközvetítőre volt szükségem, amit nem terhelnek a fenti problémák, így döntöttem a Costanza és munkatársai (1997) által kalkulált ökoszisztéma-szolgáltatási értékek százalékos formában, szorzóként való alkalmazása mellett a hatások súlyozása során.

A káros környezeti hatások azonosítása után (1. lépés, 2. táblázat) a vizsgált területet Magyarország teljes területében határoztam meg (2. lépés), mivel a megújuló energiaforrásokat érintő tervek, operatív programok és szabályozás alapvetően országos szintűek.

Következő lépésként meghatároztam az ország területén megfigyelhető ökoszisztéma-szolgáltatások értékét Costanza és munkatársai (1997) számításai alapján (3. lépés, 3. táblázat). A táblázatban a 17 ökoszisztéma-szolgáltatás éves

3. táblázat: Az ökoszisztéma-szolgáltatások értéke Magyarországon The value of ecosystem services sin Hungary

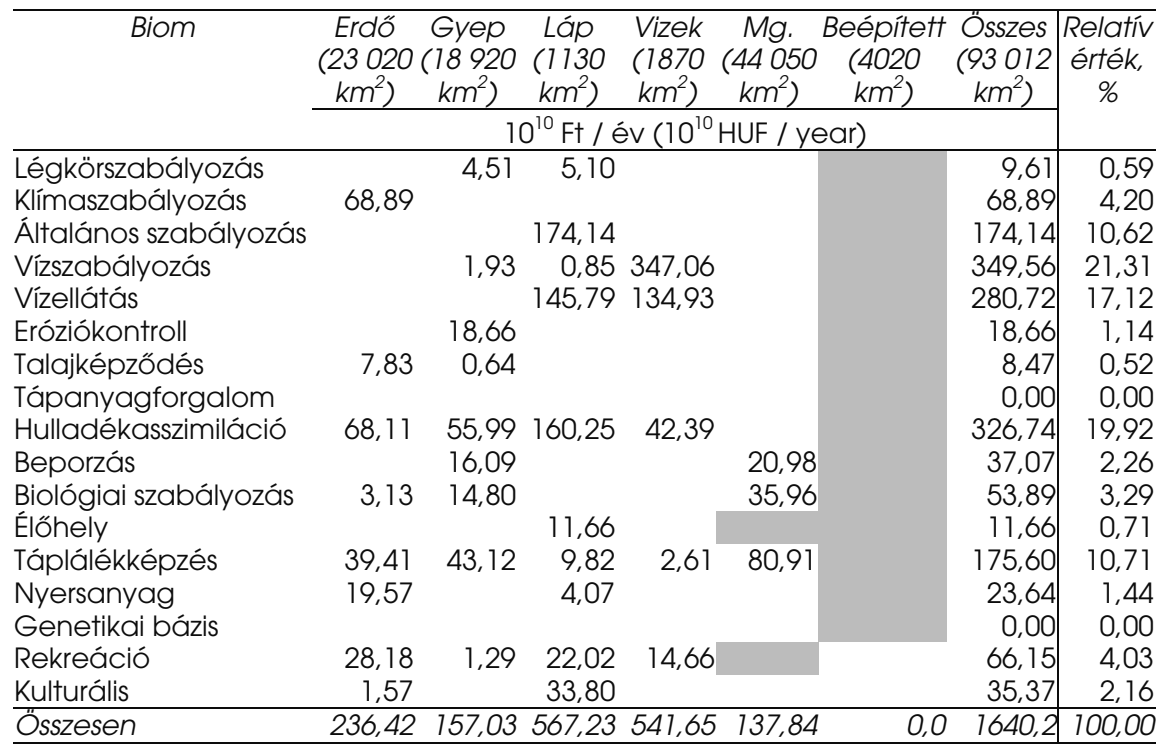

A sötétitett cellák az ökoszisztéma-szolgáltatások értékének elhanyagolhatóságát jelzik, az üres cellák pedig az adatok hiányát. Az eredeti tanulmányban közöltek szerint vettem figyelembe az ökoszisztéma-szolgáltatások értékét, bár némely esetben a szolgáltatás hiánya vagy alacsony értéke véleményem szerint megkérdőjelezhetó, pótlandó lenne. Forrás: Costanza et al. 1997 alapján saját számítás. 
értéke látható a hazánkban létező biomok teljes területén. Az adatok egyes esetekben hiányosak az eredeti tanulmányban, ezek pótlása az általam felvázolt értékelési módszer pontosítását is elősegítené. A hiányzó értékek a felmérés hiányát jelentik, aminek oka lehet egyrészt az adott biomban kevésbé jelentős szolgáltatásérték (pl. eróziókontroll a vizek, vagy nyersanyagképző funkció a gyepek esetén), másrészt az értékelés valódi hiánya.

Az ökoszisztéma-szolgáltatások közül Magyarországon a vízkészletekhez köthető érték (21,3\% és 17,1\%), valamint a hulladékasszimilicáió-érték (19,9\%) a legmagasabb. A táplálékképzés (10,7\%) és az általános szabályozás $(10,6 \%)$ szintén magas ökoszisztéma-szolgáltatási értékkel jellemezheto", ez utóbbiba tartoznak az árvízvédelmi funkciók és egyéb élőhelyvédő szolgáltatások. Az ökoszisztéma-szolgáltatások teljes értéke Magyarországon 2011-ben $1640,18 \times 10^{10}$ HUF volt ${ }^{5}$, ami a 2010-es GDP (2674 x10 10 HUF) 61,3\%-a.

Az egyes szolgáltatások aránya a táblázat utolsó oszlopában található. Egy adott hatás - amely egy adott ökoszisztéma-szolgáltatás minőségi leromlásához vezet - az adott szolgáltatáshoz tartozó aránnyal „rontja” a vizsgált terület környezetminőségét (4. lépés). Ha például egy RES-technológia olyan sok káros hatással bírna, hogy az mind a 17 szolgáltatás minőségére hat, annak a technológiának a káros hatása 100\% lenne. Ha nem tudnánk káros hatást azonosítani egy adott megújuló energiaforrásra alapozott technológiához, akkor ez az elméleti helyzet 0\%-kal lenne jellemezhetö.

A környezeti értékelés és hatásvizsgálat pontosságát természetesen emelné az ökoszisztéma-szolgáltatások minél részletesebb értékelése. A hiányzó adatok egyedileg is pótolhatók hazai környezetben elvégzett értékelési eljárások segítségével.

Végső lépésként összegeznünk kell az egyes káros hatásokhoz tartozó ökoszisztéma-szolgáltatások relatív értékét (\%) valamennyi megújuló energiaforrás tekintetében, így megkapjuk azok relatív környezeti hatását százalékos értékben. Az eredmények az 1. ábrán láthatók. A megújuló energiaforrások között megfigyelhetők magas és csekély környezeti hatással jellemezhetők. A viszonylag nagy eltéréseket a vízkészletekkel való összefüggés okozza: mint a 2. táblázatban nyomon követhetö, a biomassza, a geotermikus energia és a vízenergia mind hatással vannak a vízzel kapcsolatos szolgáltatásokra, ezért ezek környezetterhelő hatása e számítási mód szerint magasabbnak mutatkozik. Úgy gondolom, az eredmények konzisztensek az általános szakmai véleményekkel, talán a vízenergia megítélése kedvezőtlenebb, mint ahogy azt elvárhatnánk.

Természetesen a megújuló energiaforrások tekintetében azok környezeti hatása csak egy a számtalan szempont közül, amelyek a felhasználásuk irányát és a döntéseket befolyásolhatják. A káros környezeti hatások mellett mérlegelnünk kell a megújuló energiaforrások gazdasági vonatkozásait és társadalmi előnyeit (pl. munkahelyteremtés). Azzal is tisztában vagyok e tanulmány írásakor, hogy a megújuló energiaforrásokra alapozott technológiák igen különbözőek, számos hasznosítási módról és léptékről beszélhetünk, ami nehezíti az 
1. ábra: A megújuló energiaforrások relatív környezeti hatása The relative environmental impact of the renewable energy sources

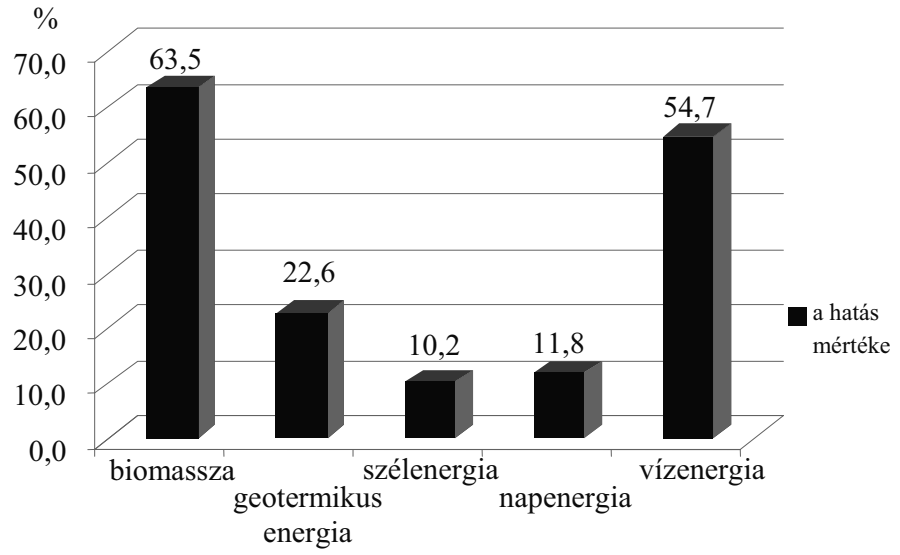

Forrás: saját szerkesztés.

általánosítást. A napenergia esetén beszélhetünk például koncentrált (naperőművek) és dekoncentrált (napkollektorok) felhasználásról, ami nyilvánvalóan különbséget jelent a környezeti hatások mértékében is. Az eredmények tovább részletezhetők annak érdekében, hogy a technológiák közti különbségek jobban előtérbe kerüljenek.

\section{A módszer hasznosíthatósága, hibái és korlátai}

Az általam felvázolt módszer új eszköz lehet a különböző típusú környezeti vizsgálatok terén. Természetesen a kapott relatív környezeti hatások értéke némi fenntartással kezelendő, a környezetpolitikai tervezésben kontroll nélkül nem alkalmazható. A tervezési és döntési eljárások során kiegészítő szerephez juthat, hiszen a konkrét ügyekben a szakértői tudást semmiképpen nem helyettesítheti. Alkalmas lehet a módszer a különböző szakértői és deliberatív eljárásokban informatív jellegű súlyok megállapítására, például az MCDA-módszerben vagy a SKV-k esetén bemutatott értékelőmátrixok pontszámainak befolyásolásában. A módszer alapvető hibaforrásai és korlátai is jól azonosíthatók azonban:

- az eredeti tanulmány (Costanza 1997) korlátai érvényesek;

- az egyes hatásokat azonos mértékűnek feltételezzük a különböző alternatívák tekintetében (fejleszthető);

- a hatás színteréből adódó különbségek nem érvényesíthetők. 


\section{Összegzés}

Az ökoszisztéma-szolgáltatások értékelésére alapozott környezeti hatásvizsgálat alkalmas lehet egyes átfogó, makroszintü fejlesztéspolitikák és környezetpolitikai döntések környezeti vizsgálatának támogatására. A módszer lépéseit felvázoltam, majd bemutattam a megújuló energiaforrások környezeti hatásainak példáján. Azonosítottam a káros környezeti hatásokat, kiszámítottam a vizsgált területen az ökoszisztéma-szolgáltatások értékét és arányait, végül összehasonlítottam a megújuló energiaforrások káros környezeti hatásait. Az eredmények alapján a szél- és a napenergia bizonyult a legkevésbé környezetterhelőnek, és a biomassza-felhasználás mutatta a környezeti hatások legnagyobb mértékét.

A módszert önálló környezeti vizsgálati eszközként nem tartom alkalmazhatónak, de fejlesztési tervek és programok előzetes értékeléséhez, valamint különböző regionális vagy országos szintű, környezeti hatással rendelkező vagy környezetvédelmi célú szabályozások (törvények, rendeletek, határozatok) ex ante hatásvizsgálatához jelentősen hozzájárulhat.

\section{Jegyzetek}

Driving force - Pressure - State - Impact - Response

willingness-to-pay, fizetési hajlandóság

Csak a kifejezetten környezeti hatásokkal foglalkozó tanulmányokat idéztem.

A beruházás során megfigyelhető káros hatásoktól eltekintettem.

Az eredeti tanulmányban 1994-es USD-értékkel számoltak a szerzők, ezt 2011-es USD-értékre számítottam át (http://www.usinflationcalculator.com/), majd 2011. 11. 03-i árfolyamon HUF-ra.

\section{Irodalom}

Alexander, A. M., List, J. A., Margolis, M., d'Arge, R. C. (1998): A method for valuing global ecosystem services. Ecological Economics, 2., 161-170.

de Almeida, A. T., Moura, P. S., Marques, A. S., de Almeida, J. L. (2005): Multi-impact evaluation of new medium and large hydropower plants in Portugal centre region. Renewable and Sustainable Energy Reviews, 1., 149-167.

Báldi A. (2011): Pénzt vagy életet? Magyar Tudomány, 7., 774-779.

Bela Gy., Pataki Gy., Valené Kelemen Á. (2003): Társadalmi részvétel a környezetpolitikai döntéshozatalban. A Budapesti Közgazdaságtudományi és Államigazgatási Egyetem Környezettudományi Intézetének Tanulmányai, 20., 1-94.

Bobok E., Tóth A. (2010): A geotermikus energia helyzete és perspektívái. Magyar Tudomány, 8., 926-936.

Chen, Z., Zhang, X. (2000): Value of ecosystem services in China. Chinese Science Bulletin, 10., 870-877. Cherubini, F., Srtomann, A. H. (2011): Life cycle assessment of bioenergy systems: State of the art 
and future challenges. Bioresource Technology, 3., 437-451.

Costanza, R. (2003): Social goals and the valuation of natural capital. Environmental Monitoring and Assessment, 86., 19-28.

Costanza, R., d'Arge, R., de Groot, R., Farber, S., Grasso, M., Hannon, B., Limburg, K., Naeem, S., O'Neill, R. V., Paruelo, J., Raskin, R. G., Sutton, P., van der Belt, M. (1997): The value of the world's ecosystem services and natural capital. Nature 387., 253-260.

Costanza, R., d'Arge, R., de Groot, R., Farber, S., Grasso, M., Hannon, B., Limburg, K., Naeem, S., O'Neill, R. V., Paruelo, J., Raskin, R. G., Sutton, P., van der Belt, M. (1998): The value of ecosystem services: putting the issues in perspective. Ecological Economics, 1., 67-72.

Czira T. (2003): A területfejlesztési tervezést támogató területi környezeti értékelés elméleti kérdései és módszertana Magyarországon. ELTE TTK, Budapest (Doktori disszertáció)

Czira T., Farkas I., Hortobágyi A., Máyer Z., Pálvölgyi T., Péti M., Szabó É., Szenci K., Vajna T. (2006): Új Magyarország Vidékfejlesztési Stratégiai Program és Terv Stratégiai környezeti vizsgálata. Budapest

Czúcz B., Kröel-Dulay Gy., Török K. (2011): Az ökoszisztéma-szolgáltatások szerepe és lehetőségei az éghajlatváltozás elleni küzdelemben. Magyar Tudomány, 7., 795-801.

Dinya L. (2010): Biomassza-alapú energiatermelés és fenntartható energiagazdálkodás. Magyar Tudomány, 8., 912-925.

de Groot, R., Wilson, M. A., Boumans, R. M. J. (2002): A typology for the classification, description and valuation of ecosystem functions, goods and services. Ecological Economics, 3., 393-408.

Hein, L., van Koppen, K., de Groot, R. S., van Ierland, E. C. (2006): Spatial scales, stakeholders and the valuation of ecosystem services. Ecological Economics, 2., 209-228.

Josimovic, B., Pucar, M. (2010): The strategic environmental impact assessment of electric wind energy plants: Case study ‘Bavanište’ (Serbia). Renewable Energy, 1509-1519.

Kelemen E., Málovics Gy., Margóczi K. (2009): Ökoszisztéma-szolgáltatások során feltárt környezeti konfliktusok az Alpári-öblözetben. Természetvédelmi Közlemények, 15. kötet, 119-133.

Kovács E., Pataki Gy., Kelemen E., Kalóczkai Á. (2011): Az ökoszisztéma-szolgáltatások fogalma a társadalomkutató szemszögéből. Magyar Tudomány, 7., 780-787.

Kristmannsdóttir, H., Ármannsson, H. (2003): Environmental aspects of geotermal utilization. Geotermics, 4-6., 451-461.

Lányi A. (2007): A fenntartható társadalom. L'Harmattan, Budapest

László M., Varjú V. (2010): Területi sajátosságok Magyarországon a stratégiai környezeti vizsgálat készítése során. Területfejlesztés és Innováció, 2., 10-19.

Lei, K., Wang, Z. (2003): The value of the ecosystem services and method. Journal of Geographical Sciences, 3., 339-347.

Málovics Gy., Bajmócy Z. (2009): A fenntarthatóság közgazdaságtani értelmezései. Közgazdasági Szemle, 5., 464-483.

Marjainé Szerényi Zs. (2005): A természetvédelemben alkalmazható közgazdasági értékelési módszerek. KVvM, Budapest

Marjainé Szerényi Zs. (2011): Az ökoszisztéma-szolgáltatások közgazdaság-tudományi megközelítése. Magyar Tudomány, 7., 788-794.

McBride, A. C., Dale, V. H., Baskaran, L. M., Downing, M. E., Eaton, L. M., Efroymson, R. A., Garten Jr., C. T., Kline, K. L., Jager, H. I., Mulholland, P. J., Parish, E. S., Schweizer, P. E., Storey, J. M. (2011): Indicators to support environmental sustainability of biomass energy systems. Ecological Indicators, 1277-1289.

Pálvölgyi T., Csete M. (2011): A fenntarthatóság felé való átmenet lehetőségei Magyarországon. Gazdálkodás, 5., 467-478.

Pearce, D. (1998): Auditing the Earth. Environment, 2., 23-28.

Phillips, J. (2010): Evaluating the level and nature of sustainable development for a geothermal power plant. Renewable and sustainable energy reviews, 8., 2412-2425.

Rybach, L. (2003): Geothermal energy: sustainability and the environment. Geotermics, 4-6., 463-470.

Saidur, R., Rahim, N. A., Islam, M. R., Solangi, K. H. (2011): Environmental impact of wind energy. Renewable and Sustainable Energy Reviews, 5., 2423-2430. 
Seidl, A. F., Moraes, A. S. (2000): Global valuation of ecosystem services: application to the Pantanal da Nhecolandia, Brazil. Ecological Economics, 1., 1-6.

Sembery P., Tóth L. (2004): Hagyományos és megújuló energiák. Szaktudás Kiadó Ház, Budapest

Stekuerová, V., Sútor, J., Nagy, V. (2008): A talajnedvesség alakulása a Csallóközben - összefüggések a környezeti és klimatikus változással. MTA RKK, Pécs

Szalai S., Gács I., Tar K., Tóth P. (2010): A szélenergia helyzete Magyarországon. Magyar Tudomány, 8., 947-958.

Szarka L. (2010): Szempontok az energetika és környezet kapcsolatához. Magyar Tudomány, 8., 979-989.

Szeredi I., Alföldi L., Csom Gy., Mészáros Cs. (2010): A vízenergia-hasznosítás szerepe, helyzete, hatásai. Magyar Tudomány, 8., 959-978.

Szilvácsku Zs., Karacs L., Varga Cs., Marjainé Szerényi Zs., Kollányi L., Vetier M. (2007a): A Gazdaságfejlesztési és Közlekedési Operatív Program környezeti vizsgálata. Budapest

Szilvácsku Zs., Varga Cs., Marjainé Szerényi Zs., Csutora M., Nemcsicsné Zsóka Á., Kiss K., Kiss G., Harangozó G., Tóth G., Vári A. (2007b): A Környezet és Energia Operatív Program környezeti vizsgálata. Budapest

Szirmai V. (1999): A környezeti érdekek Magyarországon. Pallas Stúdió, Budapest

Szirmai V., Baráth G., Molnár B., Szépvölgyi Á. (2005): Kinek az érdeke a társadalmi részvétel környezetvédelmi ügyekben? ÖKO, 1-2., 46-64.

Yu, S., Shang, J., Guo, H. (2004): Evaluation of ecological services in Jilin province, Northeast China. Chinese Geographical Science, 3., 215-220.

Varjú V. (2009): A területi tervezés legújabb környezetértékelési metódusa - a stratégiai környezeti vizsgálat integrációja a döntéshozásba. Tér és Társadalom, 1., 55-65.

VITUKI (2009): Stratégiai Környezeti Vizsgálat „Tanulmányok a Duna hajózhatóságának javításáról” program. Budapest

Wang, S., Liu, J., Wang, R., Ni, Z., Xu, S., Sun, Y. (2011): Impact of socioeconomic development on ecosystem services and its conservation strategies: a case study of Shandong Province, China. Environmental Monitoring Assessment, published online: 2011. 06. 29.

Wang, Z., Zhang, B., Zhang, S., Song, K., Duan, H. (2005): Estimates of loss in ecosystem values of Songnen Plain from 1980 to 2000. Journal of Geographical Sciences, 1., 80-86.

Tombácz E., Magyar E., Mozsgai K., Pálvölgyi T., Fleisher T., Gyulai I., Szilvácsku Zs. (2003): Stratégiai Környezeti Vizsgálat a Regionális Operatív Program környezeti szempontú ex ante értékelésének megalapozásához. Budapest

Tsoutsos, T., Frantseskaki, N., Gekas, V. (2005): Environmental impacts from solar energy technologies. Energy Policy, 3., 289-296.

Zang, S., Wu, C., Liu, H., Na, X. (2011): Impact of urbanization on natural ecosystem service values: a comparative study. Environmental Monitoring Assessment, 179., 575-588.

Zhao, B., Li, B., Zhong, J., Nakagoshi, N., Chen, J. (2005): Estimation of ecological service values of wetlands in Shanghai, China. Chinese Geographical Science, 2., 151-156. 